\title{
Dostępność kościołów parafialnych dekanatu uniejowskiego w świetle transportu indywidualnego
}

STRESZCZEN IE |Celem poniższego artykułu jest ocena dostępności pieszej, rowerem i samochodem do kościołów parafialnych wchodzących w skład dekanatu uniejowskiego. W opracowaniu uwzględniono dziesięć parafii. Do zbadania dostępności transportowej wykorzystano metodę izochronową. Na podstawie przeprowadzonych analiz przedstawiono powierzchnię zabudowy mieszkaniowej w izochronach: $0^{-5} \mathrm{~min}, 5^{-}-10 \mathrm{~min}$, IO-I5 $\mathrm{min}, 15^{-20} \mathrm{~min}, 20^{-25} \mathrm{~min}$, 25-30 min do kościołów parafialnych dekanatu uniejowskiego. Otrzymane wyniki dowodzą, że znacząca część obszaru dekanatu uniejowskiego posiada dobrą dostępność rowerem i samochodem osobowym do kościołów parafialnych. Praca ta może stać się punktem wyjścia kolejnych analiz dotyczących dostępności transportowej kościołów parafialnych, nie tylko w kontekście dekanatu, ale również na gruncie całego kraju.

SŁOWA KLUCZOWE | dostępność piesza, dostępność rowerem, dostępność samochodowa, kościół parafialny, dekanat uniejowski

\section{Wstęp}

Państwo Polskie od początku swojego istnienia nierozerwalnie związane jest z Kościołem katolickim. Obecnie coraz częściej słyszy się jednak o dużym spadku liczby wiernych w kościołach. Z różnych względów decydują się oni na rezygnację z uczestnictwa $\mathrm{w}$ obrzędach religijnych. Celem poniższego artykułu jest ocena dostępności pieszej, rowerem i samochodem do kościołów parafialnych, wchodzących w skład dekanatu uniejowskiego.

\footnotetext{
* Paulina Kurzyk, mgr, asystent, Uniwersytet Łódzki, Wydział Nauk Geograficznych, Instytut Zagospodarowania Środowiska i Polityki Przestrzennej, ul. Kopcińskiego 31, 90-I42 Łódź; e-mail: paulina.kurzyk@geo.uni.lodz.pl, https://orcid.org/oooo-oo03-2366-024X
} 
Analizowana jednostka stanowi niezwykle interesujący obszar dla badacza z dwóch powodów. Pierwszy z nich dotyczy bogatej historii funkcjonowania i tworzenia tej jednostki, która swego czasu wchodziła w skład jednej z ważniejszych diecezji na obszarze kraju. Kolejną kwestią, na którą warto zwrócić uwagę w tym kontekście, jest jej położenie na tle podziału kraju, zarówno administracyjnego, jak i kościelnego, nazywanego przestrzenno-administracyjnym. W pracy skupiono się na analizie dostępności transportowej. Pojęcie to, ogólnie ujmując, jest zdolnością zajścia relacji pomiędzy więcej niż jednym elementem danego zbioru. W relacji tej zawierają się trzy zasadnicze własności - przestrzenne, komunikacyjne i czasowe. Należy zaznaczyć, powołując się na ustalenia P. Śleszyńskiego ${ }^{2}$, że zjawisko dostępności ma charakter typowo potencjalny, a więc istnieje możliwość zajścia relacji na danym terenie przy użyciu konkretnego środka transportu w wyznaczonym czasie. Artykuł stanowi pierwsze tego typu opracowanie dotyczące dostępności transportowej kościołów parafialnych, zajmujących określony zwarty obszar w jednym dekanacie.

O roli Kościoła katolickiego w dyskusjach akademickich pisano dotychczas bardzo dużo. Ostatnio coraz częściej zwraca się uwagę na zmianę stosunku Polaków do Kościoła i postępujący spadek religijności. Są to zazwyczaj opracowania typowo socjologiczne, które skupiają się na przeobrażeniach zachodzących na równi z przemianami politycznymi w kraju po I989 r. Wśród nich warto wymienić publikacje autorstwa J. Baniaka ${ }^{3}$ czy W. Zdaniewicza i T. Zemburzuskiego ${ }^{4}$. Zdaniem M. Wenzlas na podstawie badań wykonanych przez Centrum Badania Opinii Społecznej (CBOS) działalność Kościoła coraz częściej oceniana jest negatywie. Biorąc pod uwagę zaistniałe okoliczności, wydaje się, że Kościół powinien dążyć do odzyskania wiernych, a jednym z czynników, które mogą się do tego przyczynić, jest omawiana w artykule dostępność. W tym miejscu warto wspomnieć również o pracach dotyczących Kościoła jako elementu krajobrazu,

I T. Komornicki i in., Dostępność przestrzenna jako przestanka ksztattowania polskiej polityki transportowej, „Biuletyn KPZK PAN” 20IO, z. 24I, s. I6.

2 P. Śleszyński, Dostępność czasowa i jej zastosowania, „Przegląd Geograficzny” 20I4, nr 86 (2), s. 173.

3 J. Baniak, Desakralizacja kultu religijnego i świąt religijnych $w$ Polsce. Studium socjologiczne, Kraków 2007.

4 W. Zdaniewicz, T. Zembrzuski, Kościót i religijność Polaków 1945-1999, Warszawa 2000.

5 M. Wenzel, Oceny instytucji publicznych, CBOS, Warszawa 2009. 
np. autorstwa K. Dmochowskiej-Dudek ${ }^{6}$ i E. Klimy ${ }^{7}$. W publikacjach tych omówiona jest niska pozycja Kościoła katolickiego w świadomości społecznej w kontekście krajobrazu kulturowego naszego kraju.

\section{Metody i źródła badawcze}

Dostępność transportową bada się na wiele sposobów. Wśród nich wskazać można m.in.: dostępność mierzoną wyposażeniem infrastrukturalnym (na podstawie wskaźników wyposażenia infrastrukturalnego), dostępność mierzoną odległością poprzez bezpośrednią odległość (fizyczną, rzeczywistą, czasową lub ekonomiczną do celu podróży) czy dostępność szacowaną, którą bada się, opierając się na porównywaniu alternatywnych ścieżek podróży między celem podróży a jego źródłem (czyli tzw. dostępność mierzoną w geografii czasoprzestrzeni) ${ }^{8}$. Jak twierdzi G. Sierpiński ${ }^{9}$, najczęściej wybieraną przez badaczy metodą jest jednak dostępność potencjalna, zgodnie z którą badaniu podlega potencjalna możliwość zajścia interakcji pomiędzy źródłem podróży a zbiorem celów podróży.

W poniższej pracy posłużono się metodą kumulatywną, zwaną także izochronową, na podstawie której wyznaczono obszary o takiej samej dostępności czasowej ${ }^{\mathrm{IO}}$. Dokonano analizy dotyczącej czasu dojścia pieszego, dojazdu rowerem lub samochodem osobowym do kościołów parafialnych tworzących dekanat uniejowski. W badaniu przyjęto następujące przedziały czasowe: $0^{-5} \mathrm{~min}, 5^{-}{ }^{-}$o $\mathrm{min}$, IO- ${ }^{-15} \mathrm{~min}, \mathrm{I}^{-2}-20 \mathrm{~min}, 2 \mathrm{O}^{-25} \mathrm{~min}$ i $25^{-} 30 \mathrm{~min}$. W analizie założono, że człowiek porusza się ze średnią prędkością $4,8 \mathrm{~km} / \mathrm{h}$, w kontekście poruszania się rowerem przyjęto natomiast za R. Rakowerem i in. ${ }^{I I}$ Is $\mathrm{km} / \mathrm{h}$. Analizy dotyczące dostępności samochodowej oparto na dopuszczalnych prędkościach przejazdowych, zależnych od kategorii dróg,

6 K. Dmochowska-Dudek, E. Klima, Metody analizy krajobrazu sakralnego miasta, „Prace Komisji Krajobrazu Kulturowego” 20I2, nr 17, s. I7 $\mathrm{I}^{-1} \mathrm{I} 83$.

7 E. Klima, Łódzkie kościoły katolickie po I989 roku, [w:] Duże i średnie miasta polskie w okresie transformacji, XXII Konwersatorium Wiedzy o Mieście, s. 267-279.

8 G. Sierpiński, Miary dostępności transportowej miast i regionów, „Zeszyty Naukowe. Transport / Politechnika Śląska” 20I0, z. 66, s. 91-96.

9 Tamże, s. 9I.

Io S. Wiśniewski, Zróżnicowanie dostępności transportowej miast w województwie tódzkim, Łódź 20I5, s. 25.

II R. Rakower, J. Łabędzki, J. Gadziński, Konkurencyjność ruchu rowerowego w przestrzeni miejskiej, „Transport Miejski i Regionalny” 20II, nr 2, s. 32. 
powołując się na ustalenia P. Dropa i in. ${ }^{\mathrm{I} 2} \mathrm{Na}$ potrzeby badania wykorzystano zasoby OpenStreatMap (OSM), czyli projektu stworzonego przez Steve’a Costa, będącego otwartą mapą świata z możliwością edytowania przez wszystkich użytkowników ${ }^{13}$. Obliczenia wykonano na podstawie analiz sieciowych przy pomocy programu ArcMap I0.5.I. W wyniku przeprowadzonych badań wskazano powierzchnię zabudowy jedno- i wielorodzinnej dla kościołów parafialnych w dekanacie uniejowskim. Dane dotyczące zabudowy mieszkaniowej pochodzą z Bazy Danych Obiektów Topograficznych (BDOT). W pracy zwrócono szczególną uwagę na dostępność pieszą do poszczególnych kościołów, ponieważ według autorki właśnie ona stanowi kluczowy wyznacznik uczestnictwa w życiu parafii. Jest to podyktowane wiejskim charakterem obszaru, co wiąże się również z brakiem potrzeby posiadania środka komunikacji w celu dotarcia do świątyni. Głównym dniem tygodnia, w którym znacząca część wiernych podejmuje aktywność związaną z pójściem do kościoła, jest niedziela. Biorąc pod uwagę powyższe uwarunkowania $\mathrm{w}$ artykule nie uwzględniono transportu zbiorowego, ponieważ badany obszar ma typowo wiejski charakter, a aktywność poruszana w pracy dotyczy w głównej mierze jednego dnia tygodnia - niedzieli.

Materiał źródłowy dotyczący granic poszczególnych parafii pozyskano dzięki osobom związanym z Towarzystwem Przyjaciół Uniejowa oraz pracownikom Kurii Diecezji Włocławskiej, a także od ks. infułata Andrzeja Ziemieśkiewicza - dziekana uniejowskiego. Szczególnie przydatne informacje dotyczące struktury przestrzenno-administracyjnej dekanatu uniejowskiego otrzymano w Bibliotece WSD Włocławek.

\section{Obszar badań}

Struktura administracyjno-terytorialna Kościoła katolickiego jest hierarchiczna. Nawiązuje tym samym do ogólnych zasad podporządkowania obowiązujących w Kościele Rzymskokatolickim ${ }^{\text {I4 }}$. Obszarem badawczym

\footnotetext{
I2 P. Drop, P. Gajewski, M. Mackiewicz, Zastosowanie danych OpenStreetMap oraz wolnego oprogramowania do badań dostępności komunikacyjnej w skali lokalnej, „Acta Universitatis Lodziensis. Folia Geographica Socio-Oeconomica” 2013, nr I4, s. 158.

I3 M. Borowska-Stefańska, M. Wojtczak, Dostępność piesza i transportem indywidualnym do parków w Turku i Koninie, „Biuletyn Uniejowski” 2019, t. 8, s. I64.

I4 E. Klima, Struktury Kościoła Rzymskokatolickiego w Polsce, „Acta Universitatis Lodziensis. Folia Geographica Socio-Oeconomica” 2oII, nr II, s. 2I.
} 
przyjętym w niniejszej pracy są parafie wchodzące w skład dekanatu uniejowskiego. Dekanat to słowo wywodzące się z języka łacińskiego (łac. decem, będące odpowiednikiem grec. deka, oznaczającego liczbę dziesięć) ${ }^{15}$. Definiując to pojęcie, należy na wstępie zaznaczyć, że jest ono ściśle powiązane z urzędem, który ustanowiono do kierowania tą jednostką. Według Kodeksu Prawa Kanonicznego (KPK) z I983 r. na czele dekanatu stoi wikariusz rejonowy ${ }^{16}$, tym samym dekanat jest również wikariatem rejonowym ${ }^{17}$. Ponadto funkcjonują również inne określenia, takie jak wikariat ${ }^{18}$, okręg $^{19}$, rejon ${ }^{20}$, archiprezbiterat ${ }^{21}$, wikariat zewnętrzny ${ }^{22}$. Ksiądz J. Adamczyk ${ }^{23}$ określa dekanat na podstawie KPK jako specjalny zespół, składający się z kilku sąsiadujących parafii, będących jednostkami administracyjnymi. Ich celem jest wzajemne wspieranie się podczas prowadzenia posługi pasterskiej. W tym miejscu należy także przytoczyć definicję pochodzącą z prawa partykularnego (lokalnego, miejscowego), np. archidiecezji częstochowskiej, która w swoim Statucie księży dziekanów stwierdza, że zgodnie z wielowiekową tradycją dekanat to połączenie ok. Io parafii w okręg; stanowią one jednostki organizacji terytorialnej diecezji, a na ich czele stoją księża dziekani. Ksiądz dziekan pełni funkcję pośredniczącą w konkretnych sprawach pomiędzy arcybiskupem i kurią metropolitarną a duchowieństwem i wiernymi ${ }^{24}$.

W artykule skupiono się na dekanacie uniejowskim, który położony jest na pograniczu dwóch województw - wielkopolskiego i łódzkiego. Ponadto obejmuje swym zasięgiem cztery powiaty: kolski, turecki, łęczycki i poddębicki, i osiem gmin: Grabów, Dąbie, Świnice Warckie, Uniejów, Wartkowice, Dobra, Poddębice, Pęczniew (ryc. I). Trzeba przy

I5 Sztafrowski E., Ponadparafialni wspótpracownicy biskupa diecezjalnego, „Prawo Kanoniczne: kwartalnik prawno-historyczny” 1992, t. 35, $\mathrm{nr} \mathrm{3}^{-4}$, s. 30-3I.

I6 Adamczyk J., Dekanat $i$ urzędy dekanalne, „Prawo Kanoniczne: kwartalnik prawno-historyczny" 2018, t. 6I, nr I, s. 33-5I.

I7 KPK, $374 \$ 2,553 \$ \mathrm{I}, \mathrm{AS}, \mathrm{nr} 2 \mathrm{I} 8$.

I8 KPK, $553 \$ 2,555 \$ \mathrm{I}, \mathrm{nrI}, 555 \$ 2$.

I9 $\mathrm{KPK}, 555 \$ \mathrm{I}, \mathrm{nr} 2,555 \$ 2, \mathrm{nr} 2$.

$20 \mathrm{KPK}, 555 \$ 3-4$.

2I EI, nr I86, AS, nr 2I8, por. kan. $553 \$$ I.

22 EI, nr I86.

23 J. Adamczyk, Dekanat i urzędy..., s. 23.

24 Arcybiskup Metropolita Częstochowski, Statut Księży Dziekanów Archidiecezji Częstochowskiej, [online] http://kuriaczestochowa.pl/wp-content/uploads/2013/o2/I4. pdf, [dostęp: 25.04.202I]. 


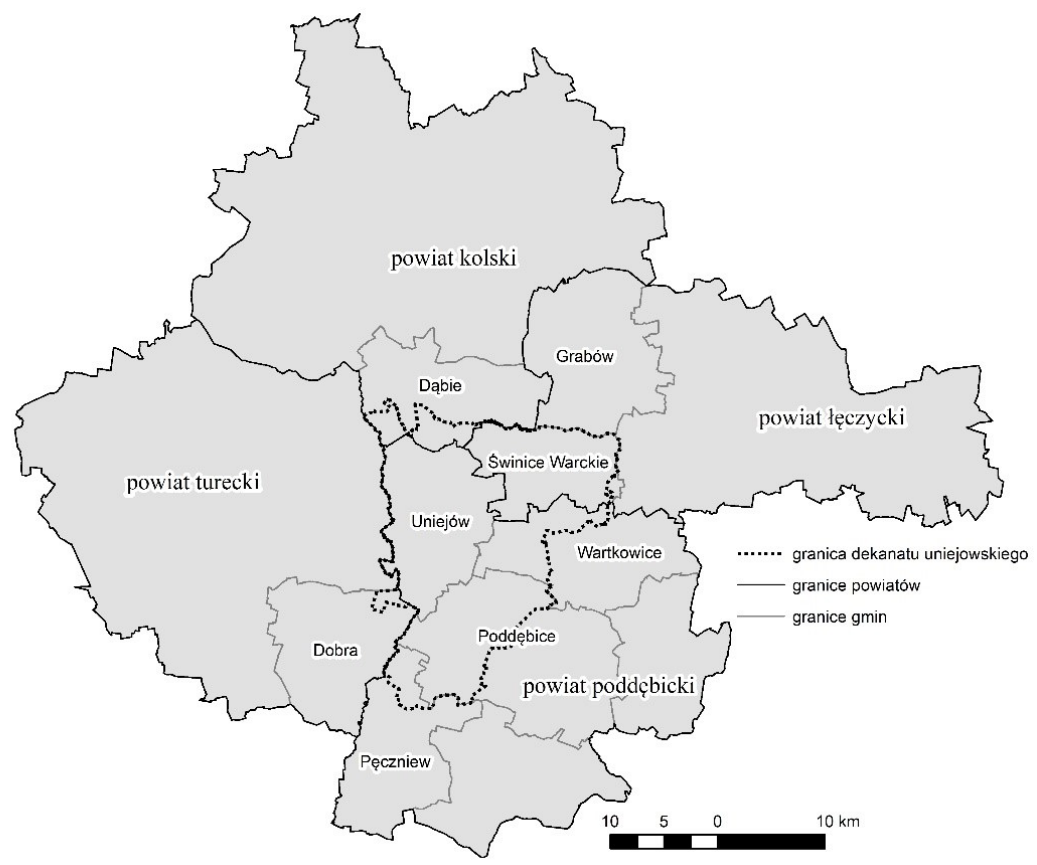

Ryc. I. Dekanat uniejowski na tle podziału administracyjnego kraju Źródło: opracowanie własne

tym zaznaczyć, że podział administracyjny kraju nie jest tożsamy z administracyjnym podziałem Kościoła katolickiego, ponieważ struktura sieci parafii nie zależy od wielkości terytorium państwa, a od liczby wiernych ${ }^{25}$. Warto podkreślić, że struktura terytorialna Kościoła katolickiego w Polsce powstała w wyniku długiego procesu, polegającego na dualizmie teologicznym i politycznym ${ }^{26}$.

Zgodnie z podziałem administracyjno-przestrzennym Kościoła katolickiego w Polsce dekanat uniejowski wchodzi w skład diecezji włocławskiej. Jest jedną z 33 tego rodzaju jednostek na tym obszarze. Dekanat został ponownie erygowany w 1990 r. przez ówczesnego biskupa ordynariusza Diecezji Włocławskiej Henryka Muszyńskiego. Wydarzenie to wiązało się również z przywróceniem do świetności kapituły uniejowskiej ${ }^{27}$.

25 E. Klima, Struktury kościoła..., s. 23.

26 Tamże.

27 Ks. Janik, Kapituła Kolegiaty Uniejowskiej. 


\section{Parafie dekanatu uniejowskiego}

Dekanat uniejowski liczy to parafii, różniących się zajmowanym obszarem oraz liczbą wiernych (tab. I). Przeprowadzona analiza obejmuje wszystkie probostwa mieszczące się w granicach wyżej wskazanego dekanatu (ryc. 2). W tym miejscu należy przyjrzeć się poszczególnym parafiom wchodzącym w skład dekanatu uniejowskiego.

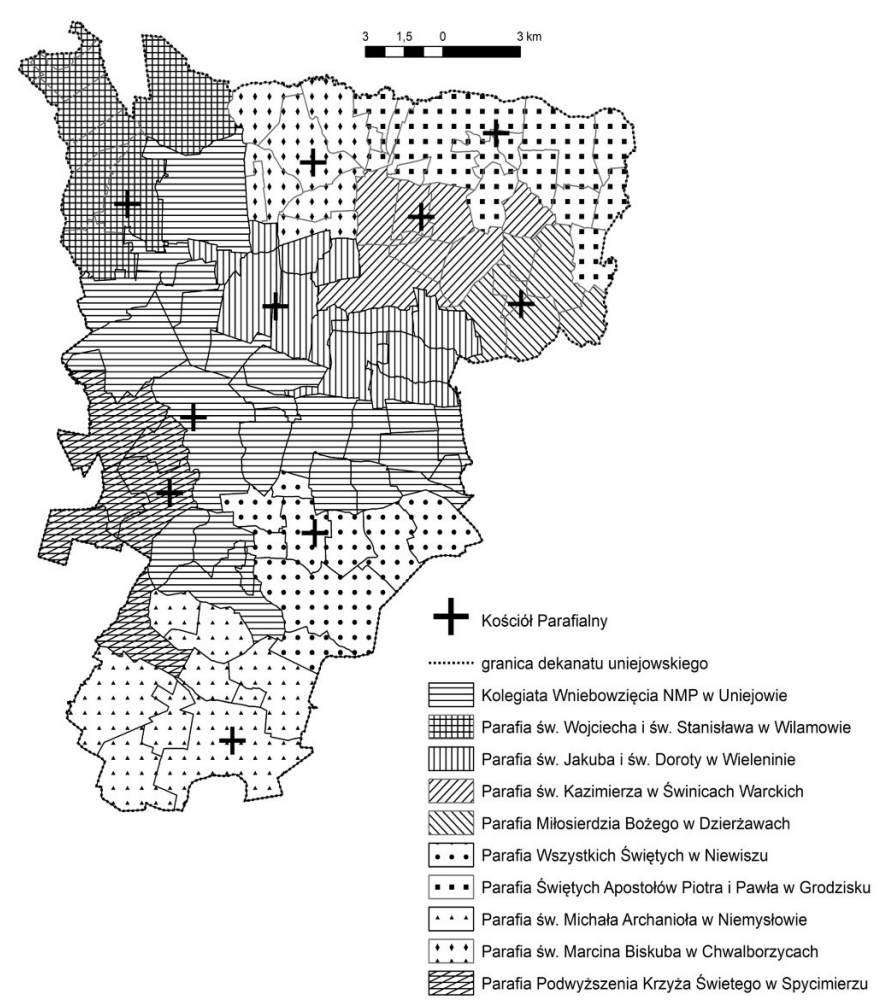

Ryc. 2. Podział administracyjno-przestrzenny dekanatu uniejowskiego na parafie Źródło: opracowanie własne na podstawie Rocznika Statystycznego Diecezji Włocławskiej 2020

Pierwsza z nich to parafia pw. św. Marcina Biskupa we Chwalborzycach. Wieś, w której znajduje się kościół parafialny, położona jest przy północnej granicy dekanatu. Cała parafia natomiast obejmuje obszar bliski $25,5 \mathrm{~km}^{2}$. Obecny kościół, jak podają źródła, wzniesiono w latach 1978-1979, jednak pierwsze wzmianki dotyczące tej parafii pochodzą z początku XV w. ${ }^{28}$

28 http://www.swinicewarckie.com.pl/asp/chwalborzyce,32,,I [dostęp: I2.02.202I]. 


\begin{tabular}{|c|c|c|c|c|c|c|}
\hline 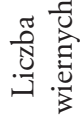 & 유 & $\tilde{\widehat{\sigma}}$ & $\begin{array}{l}\infty \\
\propto\end{array}$ & 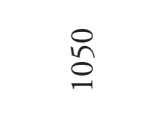 & 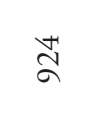 & $\vec{\sigma}$ \\
\hline 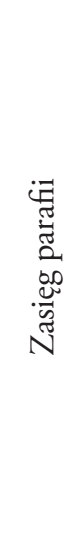 & 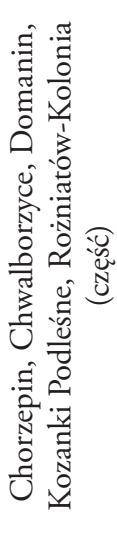 & 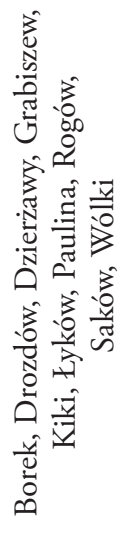 & 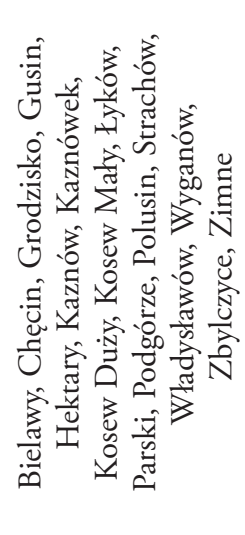 & 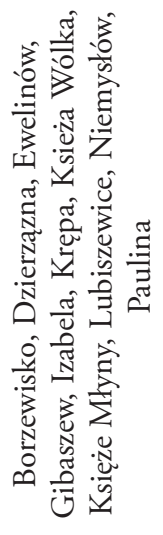 & 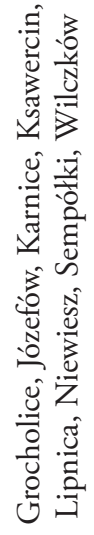 & 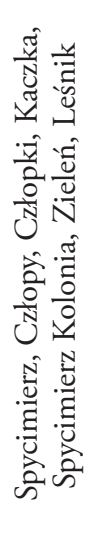 \\
\hline $\begin{array}{l}\frac{\pi}{3} \\
\frac{\pi}{3} \\
.\end{array}$ & 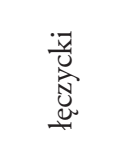 & $\begin{array}{l}\frac{\bar{y}}{0} \\
\frac{0}{0} \\
\frac{0}{0} \\
0\end{array}$ & 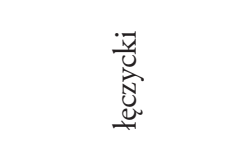 & $\begin{array}{l}\frac{\vec{y}}{0} \\
\frac{0}{0} \\
\overline{0} \\
0\end{array}$ & $\begin{array}{l}\frac{\bar{y}}{0} \\
\frac{0}{0} \\
\overline{0} \\
0 \\
0\end{array}$ & $\begin{array}{l}\vec{y} \\
\frac{\tilde{y}}{0} \\
\overline{0} \\
\overline{0} \\
0\end{array}$ \\
\hline 节 & 峁 & 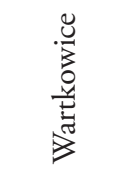 & 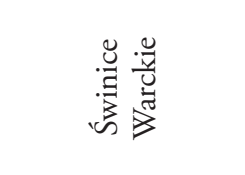 & $\begin{array}{l}\frac{\tilde{0}}{0} \\
\frac{0}{0} \\
0\end{array}$ & 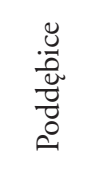 & : \\
\hline 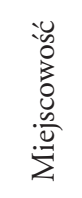 & 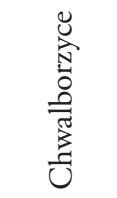 & 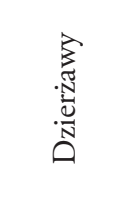 & 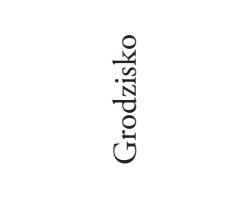 & 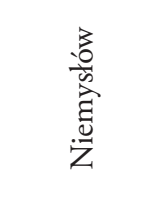 & $\frac{N}{\stackrel{N}{0}}$ & 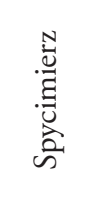 \\
\hline 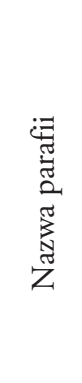 & 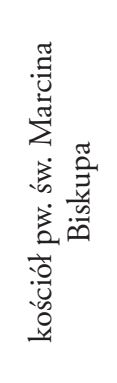 & 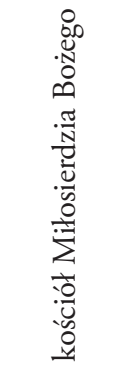 & 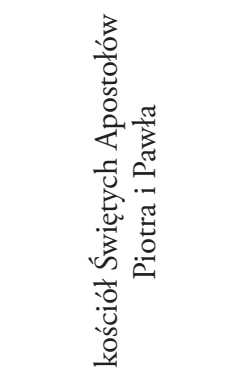 & 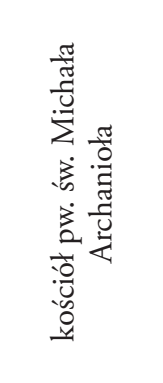 & 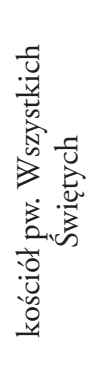 & 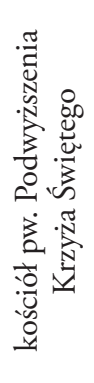 \\
\hline 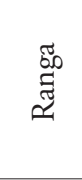 & 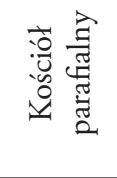 & 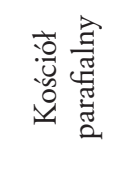 & 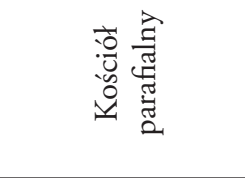 & 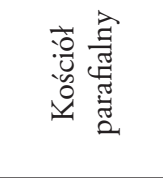 & 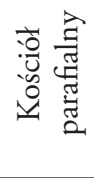 & 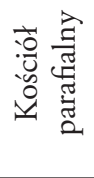 \\
\hline
\end{tabular}


Dostępność kościołów parafialnych dekanatu uniejowskiego...

\begin{tabular}{|c|c|c|c|}
\hline $\begin{array}{l}\stackrel{R}{1} \\
\text { n }\end{array}$ & $\begin{array}{l}\stackrel{n}{n} \\
n \\
n\end{array}$ & 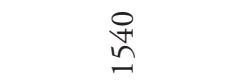 & $\stackrel{\infty}{\infty}$ \\
\hline 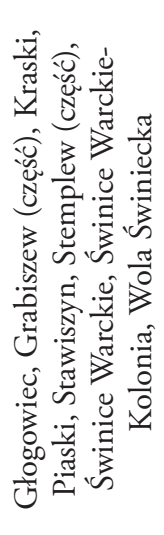 & 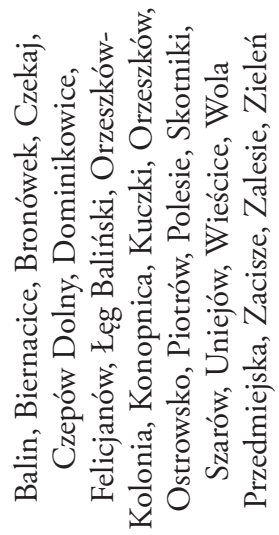 & 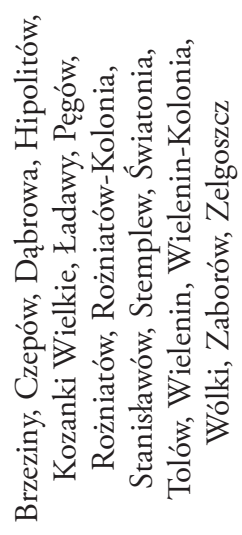 & 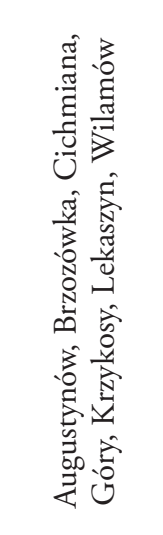 \\
\hline 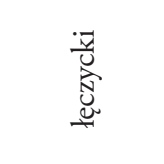 & $\begin{array}{l}\frac{i}{0} \\
: \frac{0}{0} \\
\overline{0} \\
0 \\
0\end{array}$ & 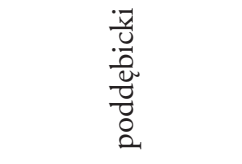 & $\begin{array}{l}\frac{i}{0} \\
\frac{0}{0} \\
\frac{\overrightarrow{0}}{0} \\
0\end{array}$ \\
\hline 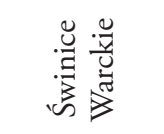 & & & : \\
\hline 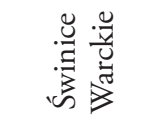 & & $\frac{\Xi}{\stackrel{\Xi}{U}}$ & 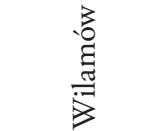 \\
\hline 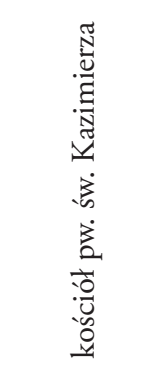 & 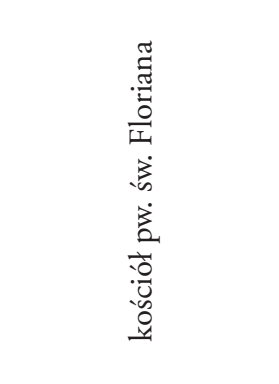 & 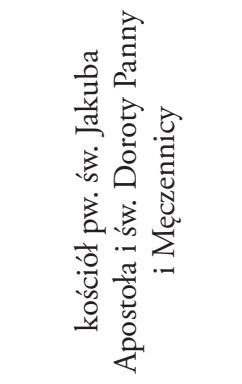 & 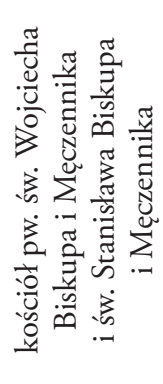 \\
\hline 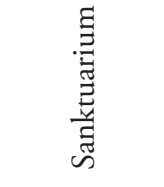 & 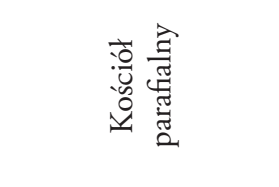 & 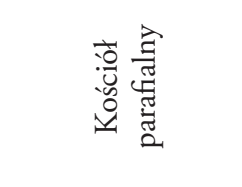 & 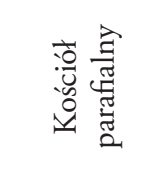 \\
\hline
\end{tabular}


Kolejną parafią wchodzącą w skład dekanatu uniejowskiego jest parafia Miłosierdzia Bożego w Dzierżawach. Warto wspomnieć, że kościół parafialny tego obszaru jest pierwszym na świecie obiektem pod wyżej wspomnianym patronatem. Parafia powstała w 1958 r. ${ }^{29}$ Obejmuje ona swym zasięgiem północno-wschodnie rubieże dekanatu, zajmując obszar niewiele ponad I3 $\mathrm{km}^{2}$.

W skład dekanatu uniejowskiego wchodzi także parafia pw. Świętych Apostołów Piotra i Pawła w Grodzisku. Jej obszar wynosi $40 \mathrm{~km}^{2}$ i jest to trzecia co do wielkości parafia w dekanacie, obejmująca w głównej mierze północo-wschodnią część gminy. Pierwsze wzmianki o parafii pochodzą z I30I r., natomiast obecny kościół parafialny wybudowano w I6I2 r. ${ }^{30}$

Parafia pw. św. Michała Archanioła w Niemysłowie obejmuje południową część dekanatu uniejowskiego, zajmując $49,5 \mathrm{~km}^{2}$. Jest to druga co do zajmowanej powierzchni parafia w badanej jednostce. Kościół parafialny, zlokalizowany w Niemysłowie, powstał w I 880 r. na miejscu wcześniejszego kościoła drewnianego, który uległ zniszczeniu w czasie pożaru ${ }^{31}$.

Kolejną wchodzącą w skład dekanatu jest parafia Wszystkich Świętych w Niewieszu. Swoim zasięgiem obejmuje $35,5 \mathrm{~km}^{2}$ i znajduje się we wschodniej części dekanatu. Obecny kościół parafialny wybudowano w latach 1970-I980, natomiast pierwsze informacje dotyczące parafii pochodzą z I $455 \mathrm{r}^{32}$

Jedną z ważniejszych jednostek na obszarze dekanatu uniejowskiego jest parafia pw. Podwyższenia Krzyża Świętego w Spycimierzu. Jej obszar stanowi $18 \mathrm{~km}^{2}$ i obejmuje zachodnią część dekanatu. Początki parafii sięgają XII w. Wtedy najprawdopodobniej wzniesiono pierwszą świątynię, natomiast obecnie istniejący kościół parafialny wybudowano w latach 1986-1992. Należy zaznaczyć, że parafia ta decyzją Ministra Kultury i Dziedzictwa Narodowego w 2018 r. została wpisana na listę niematerialnego dziedzictwa kulturowego w związku z tradycją usypywania kwietnych dywanów z okazji święta Bożego Ciała ${ }^{33}$.

Parafia pw. św. Kazimierza w Świnicach Warckich jest równocześnie Sanktuarium Urodzin i Chrztu św. Faustyny Kowalskiej. Jej obszar wynosi

29 https://sites.google.com/site/swietafaustynakowalska/pierwszy-kosciol-milosierdzia-bozego-w-dzierzawach [dostęp: I2.02.202I].

30 http://www.parafiagrodzisko.pl/page/historia-parafii/28/ [dostęp: 31.03.202I].

3I https://kosciol-niemyslow.nwcb.pl/historia/ [dostęp: 22.03.202I].

32 http://www.kultura.lodz.pl/pl/poi/3275048 [dostęp: I6.04.202I].

33 K. Smyk, Spycimierskie kwietne dywany na Boże Ciato - typologia i symbolika wzorów, „Biuletyn Uniejowski” 2019, t. 8, s. 35-65. 
$26 \mathrm{~km}^{2}$ i obejmuje północno-wschodnią część dekanatu. Parafia w związku z postacią św. Faustyny charakteryzuje się bogatą historią. W tym właśnie kościele święta została ochrzczona w 1905 r. ${ }^{34}$

Największy obszar dekanatu (niemal $100 \mathrm{~km}^{2}$ ) zajmuje parafia pw. św. Floriana w Uniejowie. Swoim zasięgiem obejmuje centralną część dekanatu uniejowskiego. Początki parafii sięgają połowy XII w. i związane są z działalnością arcybiskupów gnieźnieńskich. W tym samym czasie erygowano również kapitułę kolegiacką. Przyjmuje się także, że dzięki wysokiej pozycji w hierarchii kościelnej Uniejów w I290 r. otrzymał prawa miejskie³5.

Przedostatnią z parafii, która wchodzi w skład dekanatu uniejowskiego, jest parafia pw. św. Jakuba Apostoła i św. Doroty w Wieleninie. Teren parafii obejmuje północną część dekanatu. Jej początki sięgają XVI w. ${ }^{36}$

Parafia pw. św. Wojciecha i św. Stanisława w Wilamowie powstała w latach 20. XVI w. Jej obszar, jest terenem najbardziej wysuniętym na północ w obrębie dekanatu uniejowskiego. Swoim zasięgiem obejmuje ponad $37 \mathrm{~km}^{2}$. Kościół parafialny wzniesiono w I894 r. ${ }^{37}$

\section{Wyniki}

W wyniku przeprowadzonego badania stwierdzono, że dostępność do kościołów parafialnych w dekanacie uniejowskim jest dobra. Zauważyć to można zwłaszcza w kontekście dostępności samochodowej i rowerem (tab. 2), gdzie poszczególne wartości wynoszą odpowiednio 96\% i 97\%, biorąc pod uwagę całą zabudowę mieszkaniową w obrębie dekanatu uniejowskiego.

Największy udział wśród ogółu budynków jednorodzinnych (łącznie I I\%) w granicach dekanatu uniejowskiego stanowią te, które znajdują się w przedziale 5-Io min. W przypadku zabudowy wielorodzinnej największy odsetek mieści się w zasięgu do 5 min dojścia pieszo do kościołów parafialnych dekanatu uniejowskiego.

34 http://swfaustyna.pl/poczatki_dziejow [dostęp: 17.04.202I].

35 http://miedzywartaanerem.com.pl/zabytki/n,parafia-sw-floriana-w-uniejowie [dostęp: I0.04.202I].

36 P. Szkutnik, Regionalny poradnik genealogiczny - stan zachowania ksiag metrykalnych parafi rzymskokatolickich w gminie Uniejów, „Biuletyn Uniejowski” 20I2, t. I, s. $177^{-1} 87$.

37 http://miedzywartaanerem.com.pl/turystyka/miejsca-kultu-religijnego/n,parafia-sw-wojciecha-i-stanislawa-bm-w-wilamowie [dostęp: 16.03.202I]. 
Tabela 2. Udział powierzchni zabudowy mieszkaniowej w poszczególnych izochronach dojścia pieszego, dojazdu rowerem i samochodem osobowym w ogóle zabudowy mieszkaniowej w granicach dekanatu uniejowskiego

\begin{tabular}{|c|c|c|c|c|}
\hline \multirow{9}{*}{ 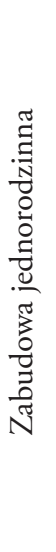 } & Czas [min] & $\begin{array}{c}\text { Dostępność } \\
\text { piesza }\end{array}$ & $\begin{array}{c}\text { Dostępność } \\
\text { rowerem }\end{array}$ & $\begin{array}{c}\text { Dostępność } \\
\text { samochodem }\end{array}$ \\
\hline & & \multicolumn{3}{|c|}{$\%$} \\
\hline & $0-5$ & 7 & 26 & 35 \\
\hline & $5-10$ & 11 & 17 & 29 \\
\hline & $10-15$ & 7 & 25 & 17 \\
\hline & $15-20$ & 6 & 13 & 6 \\
\hline & $20-25$ & 6 & 11 & 7 \\
\hline & $25-30$ & 8 & 5 & 2 \\
\hline & Suma & 45 & 97 & 96 \\
\hline \multirow{8}{*}{ 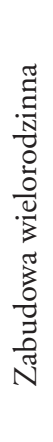 } & Czas [min] & \multicolumn{3}{|c|}{$\%$} \\
\hline & $0-5$ & 43 & 70 & 69 \\
\hline & $5-10$ & 14 & 12 & 9 \\
\hline & $10-15$ & 23 & 12 & 3 \\
\hline & $15-20$ & 3 & 3 & 0 \\
\hline & $20-25$ & 11 & 0 & 20 \\
\hline & $25-30$ & 0 & 0 & 0 \\
\hline & Suma & 94 & 97 & 100 \\
\hline
\end{tabular}

Źródło: opracowanie własne

W dalszej kolejności poddano analizie dostępność rowerem do kościołów parafialnych dekanatu uniejowskiego. W grupie tej największy odsetek (łącznie 51\%) stanową budynki jednorodzinne znajdujące się w izochronach 0-5 i IO-I5 min dojazdu rowerem do analizowanych kościołów. W przypadku zabudowy wielorodzinnej sytuacja jest odmienna. Największy odsetek tego typu budynków znajduje się bowiem w zasięgu izochrony do 5 min. Analizując przestrzenny rozkład izochron (ryc. 3), można zauważyć, że dostępność rowerem do analizowanych kościołów parafialnych jest najlepsza w centrum dekanatu uniejowskiego. Najgorzej sytuacja wygląda we wschodniej części parafii Uniejów i Wielenin.

Ostatnią część badań stanowiły analizy dotyczące dostępności samochodem do kościołów parafialnych w dekanacie uniejowskim. Po przeprowadzeniu 
badań w tej grupie stwierdzono, że podobnie jak miało to miejsce w przypadku analiz dotyczących dostępności rowerem, najwięcej budynków mieszkalnych jednorodzinnych zlokalizowanych jest w czasie do 5 min dojazdu samochodem (35\%) do badanych kościołów. Należy także zaznaczyć, że pierwsze dwa przedziały czasowe stanowią łącznie ponad 60\% wszystkich obiektów jednorodzinnych w całym dekanacie uniejowskim. Jak wynika z ryc. 2, najlepszą dostępnością samochodową charakteryzują się obszary południowe, obejmujące parafię Niemysłów, najgorszą, jak się wydaje, parafie znajdujące się na północnych rubieżach dekanatu - Grodzisko i Wilamów. Na podstawie przeprowadzonej analizy można wysunąć wniosek, że na obszarze dekanatu uniejowskiego najlepszym sposobem dotarcia do kościoła parafialnego jest wybranie roweru lub samochodu jako środka transportu.

A

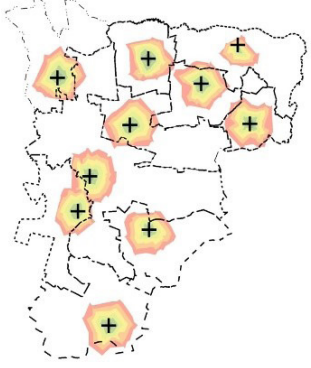

C

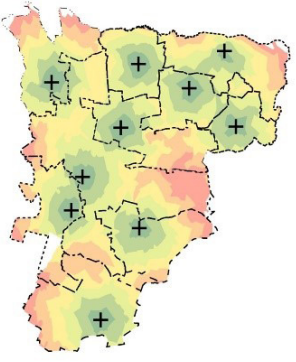

B
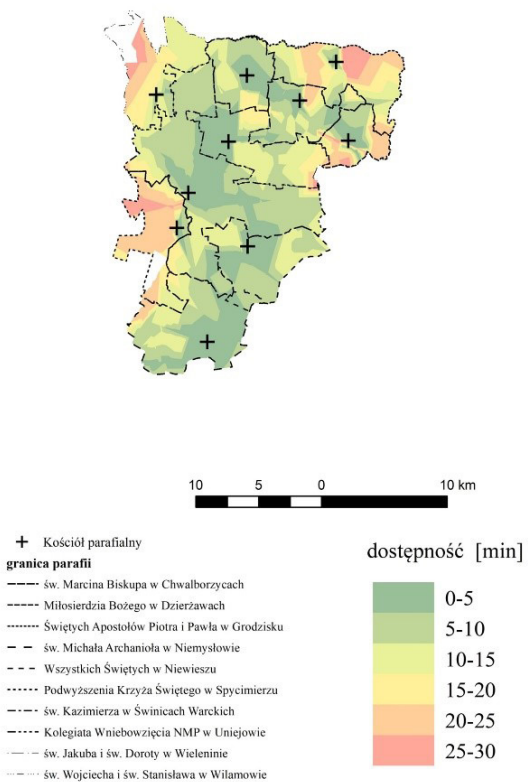

Ryc. 3. Dostępność: piesza - A, samochodem - B, rowerem - C do kościołów parafialnych dekanatu uniejowskiego

Źródło: opracowanie własne na podstawie OSM (202I r.)

Ze względu na charakter badanej jednostki, która jest w zdecydowanej większości obszarem wiejskim, w niniejszej pracy zwrócono szczególną uwagę na dostępność pieszą do poszczególnych kościołów parafialnych na obszarze dekanatu uniejowskiego. $\mathrm{Na}$ podstawie uzyskanych wyników 
można stwierdzić, że największa powierzchnia zabudowy mieszkaniowej znajduje się w zasięgu izochron powyżej Io min. Jedynie obszary parafii Niemysłów, Spycimierz, Uniejów i Świnice Warckie charakteryzują się największym udziałem powierzchni zabudowy mieszkaniowej w czasie od 5 do Io min dojścia pieszo do kościołów (tab. 3).

Najsłabszą dostępnością pieszą odznaczają się kościoły parafialne położone w Dzierżawach, Chwalborzycach i w Wilamowie.

Tabela 3. Udział powierzchni zabudowy jednorodzinnej w zasięgu dojścia pieszego do kościołów parafialnych w dekanacie uniejowskim

\begin{tabular}{|c|c|c|c|c|c|}
\hline \multirow[t]{2}{*}{$\begin{array}{c}\text { Czas dojścia } \\
\text { [min] }\end{array}$} & $\begin{array}{c}\text { Parafia } \\
\text { Niemysłów }\end{array}$ & $\begin{array}{c}\text { Parafia } \\
\text { Niewiesz }\end{array}$ & $\begin{array}{c}\text { Parafia } \\
\text { Spycimierz }\end{array}$ & $\begin{array}{c}\text { Parafia } \\
\text { Uniejów }\end{array}$ & $\begin{array}{c}\text { Parafia } \\
\text { Wielenin }\end{array}$ \\
\hline & \multicolumn{5}{|c|}{$\%$} \\
\hline $0-5$ & 11 & 20 & 22 & 18 & 13 \\
\hline $5-10$ & 24 & 10 & 44 & 32 & 17 \\
\hline $10-15$ & 14 & 14 & 12 & 24 & 24 \\
\hline $15-20$ & 13 & 19 & 4 & 13 & 19 \\
\hline $20-25$ & 15 & 15 & 10 & 8 & 11 \\
\hline $25-30$ & 23 & 22 & 8 & 5 & 16 \\
\hline Suma & 100 & 100 & 100 & 100 & 100 \\
\hline \multirow[t]{2}{*}{$\begin{array}{c}\text { Czas dojścia } \\
\text { [min] }\end{array}$} & $\begin{array}{c}\text { Parafia } \\
\text { Dzierżawy }\end{array}$ & $\begin{array}{l}\text { Parafia } \\
\text { Świnice } \\
\text { Warckie }\end{array}$ & $\begin{array}{c}\text { Parafia } \\
\text { Grodzisko }\end{array}$ & $\begin{array}{c}\text { Parafia } \\
\text { Chwalborzyce }\end{array}$ & $\begin{array}{c}\text { Parafia } \\
\text { Wilamów }\end{array}$ \\
\hline & \multicolumn{5}{|c|}{$\%$} \\
\hline $0-5$ & 3 & 17 & 2 & 9 & 25 \\
\hline $5-10$ & 14 & 29 & 17 & 11 & 14 \\
\hline $10-15$ & 15 & 9 & 13 & 14 & 7 \\
\hline $15-20$ & 10 & 10 & 24 & 15 & 9 \\
\hline $20-25$ & 18 & 13 & 22 & 16 & 18 \\
\hline $25-30$ & 40 & 22 & 22 & 35 & 27 \\
\hline Suma & 100 & 100 & 100 & 100 & 100 \\
\hline
\end{tabular}

Źródło: opracowanie własne 
Przeprowadzone postępowanie badawcze można skonfrontować z wynikami uzyskanymi przez L. Groeger ${ }^{38}$ podczas badań przeprowadzonych wśród co prawda miejskich przestrzeni mieszkaniowych w odniesieniu do lokalnej społeczności. Badania te dowiodły, że kościół to istotny obiekt zagospodarowania, co świadczy o tym, że dostępność stanowi ważny aspekt jego funkcjonowania. Tym samym nie bez znaczenia, zwłaszcza dla mieszkańców obszarów wiejskich, będzie położenie i możliwość dotarcia do obiektu kultu religijnego, jakim jest kościół parafialny. W wielu badaniach zwraca się uwagę również na fakt, że kościół może być traktowany także jako obiekt kulturowy i stanowić cel turystyczny. Jednym z tego typu obiektów, spośród opisywanych wcześniej kościołów parafialnych, jest bez wątpienia kościół w Świnicach Warckich, znany powszechnie jako Sanktuarium Urodzin i Chrztu św. Faustyny. Należy podkreślić, na co zwrócił uwagę Armin Mikos von Rohrscheidt ${ }^{39}$, że turystyka o charakterze pielgrzymkowym będzie cieszyć się coraz większą popularnością, co wynika z polskiej religijności, a zatem dostosowanie dostępności do obiektów sakralnych wydaje się nieuniknione. Warto także wspomnieć, powołując się na pracę A. Rydzewskiej ${ }^{+0}$, o konieczności szerzenia świadomości historii danych obiektów i terenów sakralnych wśród lokalnej społeczności. W tym kontekście powyższe badanie dowodzi, że większość mieszkańców dekanatu uniejowskiego ma możliwość dotarcia do obiektów sakralnych o dużych walorach historyczno-kulturowych.

\section{Wnioski}

Badanie dostępności transportowej jest niezwykle ważnym aspektem kształtowania lokalnej polityki transportowej. Dzięki tego typu analizom samorządy mogą pozyskiwać niezbędne dane, służące ulepszeniu funkcjonującego systemu transportowego. W powyższym artykule zbadano dostępność transportową (pieszo, rowerem i samochodem) do kościołów parafialnych mieszczących się w granicach dekanatu uniejowskiego. Poligon badawczy

38 L. Groeger, Zagospodarowanie miejskiej przestrzeni mieszkaniowej w aspekcie potrzeb spoteczności lokalnych, „Acta Universitatis Lodziensis. Folia Geographica Socio-Oeconomica” 20I6, nr 24 (2), s. 29-43.

39 Armin Mikos von Rohrscheidt, Faktyczna dostępność turystyczna obiektów sakralnych jako problem turystyki religijnej w Polsce, „Ekonomiczne Problemy Usług” 20II, nr 65, s. 56. 40 A. Rydzewska, Sacrum w krajobrazie otwartym i miejskim - funkcje i zagrożenia, „Prace Komisji Krajobrazu Kulturowego” 2013, nr 22, s. II2. 
okazał się niezwykle interesujący, m.in. ze względu na konfrontację jego położenia w kontekście podziału przestrzenno-administracyjnego Kościoła katolickiego w Polsce z podziałem administracyjnym kraju. Z badań wynika, że mieszkańcy tego terenu cieszą się stosunkowo dobrą dostępnością transportową do kościołów parafialnych, zwłaszcza rowerem i samochodem. Wynik ten dowodzi, że wierni posiadający jeden z wymienionych środków transportu nie mają większych problemów z dotarciem do miejsca kultu. Sytuacja nie jest tak korzystna w odniesieniu do podróży odbywającej się pieszo. Dodatkowo z punktu widzenia atrakcyjności celu podróży, którym w tym wypadku jest kościół parafialny, uzyskane wyniki świadczą o tym, że niemal każdy mieszkaniec dekanatu uniejowskiego ma możliwość dotarcia do świątyni w ciągu 30 min - zarówno pieszo, rowerem, jak i samochodem. Niniejsza praca może stać się przyczynkiem do dalszych badań dotyczących szczegółowej diagnozy dostępności dla każdej z parafii wchodzącej w skład dekanatu uniejowskiego, jak również odnoszących się do wykluczenia transportowego, które niewykluczone, że ma związek ze zmniejszającą się liczbą wiernych w kościołach.

\section{Bibliografia}

Adamczyk J., Dekanat i urzędy dekanalne, „Prawo Kanoniczne: kwartalnik prawno-historyczny" 20I8, t. 6I, nr I, s. 33-5I. https://doi.org/I0.21697/ pk.2018.6r.I.03

Arcybiskup Metropolita Częstochowski, Statut Księży Dziekanów Archidiecezji Częstochowskiej.

Baniak J., Desakralizacja kultu religijnego $i$ swiąt religijnych $w$ Polsce. Studium socjologiczne, Kraków 2007.

Borowska-Stefańska M.. Wojtczak M., Dostępność piesza i transportem indywidualnym do parków w Turku i Koninie, „Biuletyn Uniejowski” 2019, t. 8, s. 164. https://doi.org/I0.18778/2299-8403.08.10

Dmochowska-Dudek K., Klima E., Metody analizy krajobrazu sakralnego miasta, „Prace Komisji Krajobrazu Kulturowego” 20I2, nr I7, s. I7I-I83.

Drop P., Gajewski P., Mackiewicz M., Zastosowanie danych OpenStreetMap oraz wolnego oprogramowania do badań dostęnności komunikacyjnej w skali lokalnej, „Acta Universitatis Lodziensis. Folia Geographica Socio-Oeconomica" 2013, nr I4, s. I57-167. 
EI, nr I86, AS, nr 218, por. kan. $553 \$$ I; EI, nr I86.

Groeger L., Zagospodarowanie miejskiej przestrzeni mieszkaniowej w aspekcie potrzeb społeczności lokalnych, „Acta Universitatis Lodziensis. Folia Geographica Socio-Oeconomica” 20I6, nr 24 (2), s. 29-43. https://doi. org/IO.I8778/I508-III7.24.03

Klima E., Eódzkie kościoły katolickie po 1989 roku, [w:] Duże i średnie miasta polskie w okresie transformacji, XXII Konwersatorium Wiedzy o Mieście, Łódź 2009, s. 267-279.

Klima E., Struktury Kościoła Rzymskokatolickiego w Polsce, „Acta Universitatis Lodziensis. Folia Geographica Socio-Oeconomica” 20II, nr II, s. I-34.

Kodeks Prawa Kanonicznego, 374 \$ 2, $553 \$$ I, AS, nr 2I8; $553 \$ 2,555 \$$ I, nr I, $555 \$ 2 ; 555 \$ \mathrm{I}, \mathrm{nr} 2,555 \$ 2, \mathrm{nr} 2 ; 555 \$ 3-4$.

Komornicki T. i in., Dostępność przestrzenna jako przesłanka kształtowania polskiej polityki transportowej, „Biuletyn KPZK PAN” 20IO, z. 24I, s. I6. Mikos von Rohrscheidt A., Faktyczna dostępność turystyczna obiektów sakralnych jako problem turystyki religijnej w Polsce, „Ekonomiczne Problemy Usług” 20II, nr 65, s. 35-57.

Rakower R., Łabędzki J., Gadziński J., Konkurencyjność ruchu rowerowego w przestrzeni miejskiej, „Transport Miejski i Regionalny” 20II, nr 2, s. 32.

Rocznik Statystyczny Diecezji Włocławskiej 2020, WSD Włocławek.

Rydzewska A., Sacrum w krajobrazie otwartym i miejskim-funkcje izagrożenia, „Prace Komisji Krajobrazu Kulturowego” 20I3, nr 22, IO5-II2.

Sierpiński G., Miary dostępności transportowej miast i regionów, „Zeszyty Naukowe. Transport / Politechnika Śląska” 20Io, z. 66, s. 9I-96.

Smyk K., Spycimierskie kwietne dywany na Boże Ciało - typologia i symbolika wzorów, „Biuletyn Uniejowski” 2019, t. 8, s. 35-65. https:// doi.org/I0.18778/2299-8403.08.03

Szkutnik P., Regionalny poradnik genealogiczny - stan zachowania ksiag metrykalnych parafii rzymskokatolickich w gminie Uniejów, „Biuletyn Uniejowski” 20I2, t. I, s. I77-187.

Sztafrowski E., Ponadparafialni współpracownicy biskupa diecezjalnego, „Prawo Kanoniczne: kwartalnik prawno-historyczny” I992, t. 35, nr 3-4, s. 25-56. https://doi.org/Io.21697/pk.1992.35.3-4.02

Śleszyński P., Dostępność czasowa i jej zastosowania, „Przegląd Geograficzny” 20I4, nr 86 (2), s. 73. https://doi.org/Io.7I63/PrzG.20I4.2.2

Wenzel M., Oceny instytucji publicznych, СвOS, Warszawa 2009. 
Wiśniewski S., Zróżnicowanie dostępności transportowej miastw województwie tódzkim, Łódź 20I5, s. 25. https://doi.org/IO.I8778/7969-52I-8

Zdaniewicz W., Zembrzuski T., Kościót i religijność Polaków I945-I999, Warszawa 2000.

\section{Źródła internetowe}

http://kuriaczestochowa.pl/wp-content/uploads/2013/o2/I4.pdf, [dostęp: 25.04.202I].

http://mied zywartaanerem.com.pl/turystyka/miejsca-kultu-religijnego/ n,parafia-sw-wojciecha-i-stanislawa-bm-w-wilamowie [dostęp: I6.03.202I]. http://miedzywartaanerem.com.pl/zabytki/n,parafia-sw-floriana-w-uniejowie [dostęp: I0.04.2021]. http://swfaustyna.pl/poczatki_dziejow [dostęp: 17.04.202I]. http://www.kultura.lodz.pl/pl/poi/3275048 [dostęp: I6.04.202I]. http://www.parafiagrodzisko.pl/page/historia-parafii/28/ [dostęp: 3I.03.202I]. http://www.swinicewarckie.com.pl/asp/chwalborzyce,32,,I [dostęp: I2.02.202I]. https://kosciol-niemyslow.nwcb.pl/historia/ [dostęp: 22.03.202I]. https://sites.google.com/site/swietafaustynakowalska/pierwszy-kosciolmilosierdzia-bozego-w-dzierzawach [dostęp: I2.02.202I].

\section{Accessibility of parish churches in Uniejów decanate by individual transport}

SUMMARY | The purpose of this article is to assess the pedestrian, bicycle and car accessibility of parish churches in Uniejów decanate. The study covers ten parishes. To examine transport accessibility, the isochrone method was used. Based on the conducted analysis, the housing areas have been presented in isochrones: O-5 min, IO-I5 min, I5-20 min, 20-25 min, and 25-30 min to Uniejów decanate parish churches. The obtained results show that most of this area has good bicycle and transport accessibility. This study can provide a starting point for further analyses of this issue at the scale of the country as a whole.

KEYWOR D S foot accessibility, bicycle accessibility, car accessibility, parish church, Uniejów decanate

| Informacje o artykule: przyjęto - I9 maja 202I; zaakceptowano 2I czerwca 202I 